\title{
Activity of ampicillin in vitro compared with other antibiotics
}

\author{
R. SUTHERLAND AND G. N. ROLINSON \\ From the Beecham Research Laboratories Limited, \\ Research Division, Betchworth, Surrey
}

SYNOPSIS Comparative tests in vitro for antibacterial activity were carried out with ampicillin, tetracycline, and chloramphenicol using 673 clinical isolates of Gram-negative bacilli and Streptococcus faecalis. Further comparative tests were also carried out with ampicillin, chloramphenicol, colistin sulphate, colistin methane sulphonate, cycloserine, kanamycin, nitrofurantoin, polymyxin, streptomycin, and tetracycline, using groups of 20 strains of each of the main species selected at random from the total number of isolates. Of the total number of isolates a higher percentage was inhibited by ampicillin than by tetracycline or chloramphenicol. Ampicillin showed particularly high activity against certain species of bacteria and displayed an antibacterial spectrum not shown by any of the other antibiotics tested.

Ampicillin(6[D(-)a-aminophenylacetamido]penicillanic acid) is a penicillin with broad-spectrum activity (Rolinson and Stevens, 1961). The compound is acid stable and gives satisfactory serum concentrations after oral administration (Knudsen, Rolinson, and Stevens, 1961). Ampicillin shows a very low order of toxicity (Acred, Brown, Turner, and Wilson, 1962) and the early clinical experience with ampicillin was reported by Stewart, Coles, Nixon, and Holt (1961); Bunn (1961); Rutenberg, Greenberg, Schweinburg, and Perreault (1961); Brumfitt, Percival, and Carter (1962); and Trafford, Maclaren, Lillicrap, Barnes, Houston, and Knox (1962).

The antibacterial spectrum of ampicillin includes the pyogenic cocci, enterococci, Neisseria species including the gonococcus, Haemophilus influenzae, Salmonella species, and strains of Escherichia coli, Shigella and Proteus. Not all strains of these organisms are uniformly sensitive to ampicillin, however, and conflicting statements regarding the activity of this penicillin have appeared in the literature, particularly against coliforms and Proteus species.

\section{METHODS}

A total of 673 strains of bacteria was obtained from the Middlesex Hospital, the West Middlesex Hospital, and

Received for publication January 101964.
St. Thomas's Hospital, London. Nearly all the cultures had been associated with urinary tract infections and were received as isolated routinely without selection of any kind.

CLASSIFICATION The cultures were supplied on agar slopes and were cultured on MacConkey's agar, from which mixed cultures were separated into pure cultures.

The $E$. coli group was defined as lactose-fermenting, non-citrate utilizing bacteria; this group included indole-positive (type I) and indole-negative (intermediate coliforms) organisms. Lactose-fermenting, citrate-utilizing, indole-negative bacteria were classified as Aerobacter aerogenes.

Proteus species were identified with some considerable care in view of the wide variation in sensitivity of these organisms to ampicillin, and classification was based on the biochemical tests as reported by Mackie and McCartney (1962). The majority of Proteus strains encountered in this study belonged to the species Proteus mirabilis; other Proteus species were rare.

The remainder of the non-lactose fermenting, non-ureahydrolysing organisms were tested for phenylpyruvic acid production by the method of Stewart (1961) in order to isolate providencia (Proteus inconstans) organisms; these strains were also tested for $\beta$-(D)-galactosidase production (Lowe, 1962) to isolate late-lactose fermenting cultures which would be classified as paracolon bacteria. Pseudomonas was distinguished by the characteristic odour and production of green pigment on MacConkey's medium, although in some instances weak reactions were confirmed by culture in Hugh and Leifson's medium, and by tests to demonstrate utilization of arginine (Thornley, 1960). 
Streptococcus faecalis was identified by colonial appearance on MacConkey's agar and Gram-stain reaction.

ANTIBIOTIC SENSITIVITIES Minimum inhibitory concentrations were determined by serial dilution in agar. A loop of an overnight broth culture was used as inoculum and the plates were incubated at $37^{\circ} \mathrm{C}$. overnight.

\section{RESULTS}

COMPARATIVE ACTIVITIES OF AMPICILLIN, CHLORAMPHENICOL, AND TETRACYCLINE Of the 673 isolates tested for sensitivity to ampicillin, chloramphenicol, and tetracycline, the predominant organism was $E$. coli. This accounted for $40 \%$ of the total number. Proteus mirabilis was the next most common pathogen $(24 \%)$; other species of Proteus, namely $P$. vulgaris and $P$. morganii, comprised only $2 \%$ of the total. The remainder was accounted for by Aerobacter aerogenes $(12 \%)$, Streptococcus faecalis $(10 \%)$, Pseudomonas pyocyanea (7\%), and miscellaneous organisms, comprising mainly paracolon and some achromobacter bacteria, $(6 \%)$. The antibiotic sensitivities of the bacteria are shown in Table $I$. Of the total of 269 strains of $E$. coli, $78 \%$ were inhibited by $5 \mu \mathrm{g} . / \mathrm{ml}$. or less of ampicillin. The corresponding figures for chloramphenicol and tetracycline were $52 \%$ and $64 \%$, respectively. At

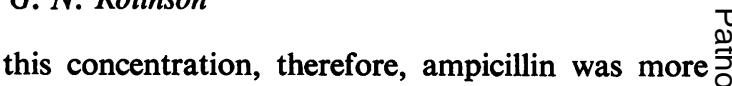
effective than either chloramphenicol or tetracycline. At the lower concentration of $2.5 \mu \mathrm{g}$. $/ \mathrm{ml}$., however, only $19 \%$ were inhibited by ampicillin whereas with tetracycline the corresponding figure was $45 \%$ and for chloramphenicol only $8 \%$.

Resistance of $E$. coli to ampicillin was not $\overparen{\mathbb{Q}}$ associated with resistance to tetracycline or chloramphenicol. The strains resistant to tetracycline or ${ }^{\infty}$ chloramphenicol were as sensitive to ampicillin as $\vec{\circ}$ was the total number of isolates tested.

The strains of $P$. mirabilis were generally highly $\vec{\omega}$ sensitive to ampicillin, $83 \%$ being inhibited by a concentration of $5.0 \mu \mathrm{g}$. $/ \mathrm{ml}$. and $74 \%$ by $2.5 \mu \mathrm{g} . / \mathrm{ml}$. Both chloramphenicol and tetracycline were considerably less active at these concentrations. In contrast with $P$. mirabilis, all the strains of $P$. $\stackrel{\circ}{\vec{S}}$ morganii and $P$. vulgaris were relatively resistant to $\circ$ ampicillin.

Ampicillin was highly active against the isolates $\vec{c}$ of Streptococcus faecalis, $95 \%$ being inhibited by $2.5 \mu \mathrm{g} . / \mathrm{ml}$. whereas chloramphenicol and tetra- $\vec{\oplus}$ cycline were relatively ineffective. Against strains of $\$$ Aerobacter aerogenes, ampicillin generally showed a low order of activity. Of a total of 80 strains, however, $20 \%$ were inhibited by $5.0 \mu \mathrm{g} . / \mathrm{ml}$. or less of ampicillin. Similarly, not all paracolon organisms were resistant to ampicillin, about half of the strains tested being inhibited by $5.0 \mu \mathrm{g} . / \mathrm{ml}$. ampicillin.

\section{TABLE I}

ACTIVITY OF AMPICILLIN, CHLORAMPHENICOL, AND TETRACYCLINE AGAINST 673 STRAINS OF GRAM-NEGATIVE BACTERIA AND ENTEROCOCCI

\begin{tabular}{|c|c|c|c|c|c|c|c|c|c|c|c|c|c|c|}
\hline \multirow[t]{2}{*}{ Organism } & \multirow[t]{2}{*}{ Antibiotic } & \multirow{2}{*}{$\begin{array}{l}\text { Number } \\
\text { of } \\
\text { Strains }\end{array}$} & \multirow{2}{*}{$\begin{array}{c}\text { Percentage } \\
\text { of Total }\end{array}$} & \multicolumn{11}{|c|}{ Minimum Inhibitory Concentrations $(\mu \mathrm{g} . / \mathrm{ml}$.) and No. of Strains } \\
\hline & & & & $>250$ & 250 & 125 & 50 & 25 & $12 \cdot 5$ & $5 \cdot 0$ & $2 \cdot 5$ & $1 \cdot 25$ & 0.5 & $0 \cdot 25$ \\
\hline E. coli & $\begin{array}{l}\text { Ampicillin } \\
\text { Chloramphenicol } \\
\text { Tetracycline }\end{array}$ & $\begin{array}{l}269 \\
270 \\
259\end{array}$ & $40 \cdot 0$ & $\begin{array}{r}8 \\
15 \\
11\end{array}$ & $\begin{array}{r}2 \\
3 \\
20\end{array}$ & $\begin{array}{r}4 \\
2 \\
13\end{array}$ & $\begin{array}{r}3 \\
4 \\
11\end{array}$ & $\begin{array}{r}1 \\
6 \\
23\end{array}$ & $\begin{array}{r}39 \\
101 \\
13\end{array}$ & $\begin{array}{r}161 \\
116 \\
50\end{array}$ & $\begin{array}{l}46 \\
12 \\
59\end{array}$ & $\begin{array}{r}5 \\
9 \\
54\end{array}$ & $\begin{array}{l}2 \\
3\end{array}$ & 2 \\
\hline $\begin{array}{l}\text { Proteus } \\
\text { mirabilis }\end{array}$ & $\begin{array}{l}\text { Ampicillin } \\
\text { Chloramphenicol } \\
\text { Tetracycline }\end{array}$ & $\begin{array}{l}156 \\
156 \\
156\end{array}$ & $23 \cdot 2$ & $\begin{array}{r}11 \\
1 \\
16\end{array}$ & $\begin{array}{l}3 \\
3\end{array}$ & $\begin{array}{r}3 \\
6 \\
17\end{array}$ & $\begin{array}{r}2 \\
5 \\
98\end{array}$ & $\begin{array}{r}5 \\
6 \\
14\end{array}$ & $\begin{array}{r}5 \\
89 \\
1\end{array}$ & $\begin{array}{r}14 \\
41 \\
1\end{array}$ & $\begin{array}{r}80 \\
4 \\
4\end{array}$ & $\begin{array}{r}36 \\
1 \\
2\end{array}$ & & \\
\hline $\begin{array}{l}\text { Streptococcus } \\
\text { faecalis }\end{array}$ & $\begin{array}{l}\text { Ampicillin } \\
\text { Chloramphenicol } \\
\text { Tetracycline }\end{array}$ & $\begin{array}{l}67 \\
66 \\
67\end{array}$ & $10 \cdot 0$ & $\begin{array}{l}1 \\
1\end{array}$ & 10 & $\begin{array}{r}1 \\
3 \\
17\end{array}$ & $\begin{array}{l}8 \\
3\end{array}$ & $\begin{array}{l}2 \\
4\end{array}$ & $\begin{array}{r}1 \\
34 \\
3\end{array}$ & $\begin{array}{r}12 \\
5\end{array}$ & $\begin{array}{r}21 \\
6 \\
7\end{array}$ & $\begin{array}{r}37 \\
1 \\
13\end{array}$ & $\begin{array}{l}3 \\
4\end{array}$ & 3 \\
\hline $\begin{array}{l}\text { Aerobacter } \\
\text { aerogenes }\end{array}$ & $\begin{array}{l}\text { Ampicillin } \\
\text { Chloramphenicol } \\
\text { Tetracycline }\end{array}$ & $\begin{array}{l}80 \\
80 \\
80\end{array}$ & $11 \cdot 9$ & $\begin{array}{r}25 \\
10 \\
5\end{array}$ & $\begin{array}{l}7 \\
3 \\
8\end{array}$ & $\begin{array}{l}5 \\
3 \\
6\end{array}$ & $\begin{array}{r}13 \\
4 \\
6\end{array}$ & $\begin{array}{r}5 \\
2 \\
15\end{array}$ & $\begin{array}{r}9 \\
18 \\
5\end{array}$ & $\begin{array}{r}11 \\
26 \\
6\end{array}$ & $\begin{array}{l}2 \\
5 \\
9\end{array}$ & $\begin{array}{r}3 \\
8 \\
17\end{array}$ & $\begin{array}{l}1 \\
2\end{array}$ & 1 \\
\hline $\begin{array}{l}\text { Pseudomonas } \\
\text { pyocyanea }\end{array}$ & $\begin{array}{l}\text { Ampicillin } \\
\text { Chloramphenicol } \\
\text { Tetracycline }\end{array}$ & $\begin{array}{l}47 \\
47 \\
47\end{array}$ & $7 \cdot 0$ & $\begin{array}{r}40 \\
4 \\
15\end{array}$ & $\begin{array}{l}4 \\
4 \\
9\end{array}$ & $\begin{array}{r}25 \\
6\end{array}$ & $\begin{array}{r}2 \\
10 \\
9\end{array}$ & $\begin{array}{l}1 \\
7\end{array}$ & 2 & $\begin{array}{l}1 \\
1\end{array}$ & 1 & & & \\
\hline Miscellaneous $^{1}$ & $\begin{array}{l}\text { Ampicillin } \\
\text { Chloramphenicol } \\
\text { Tetracycline }\end{array}$ & $\begin{array}{l}40 \\
40 \\
40\end{array}$ & $6 \cdot 0$ & $\begin{array}{l}5 \\
1 \\
2\end{array}$ & $\begin{array}{l}3 \\
1 \\
6\end{array}$ & $\begin{array}{l}3 \\
2 \\
1\end{array}$ & $\begin{array}{l}1 \\
1 \\
3\end{array}$ & $\begin{array}{l}4 \\
3 \\
2\end{array}$ & $\begin{array}{r}5 \\
15 \\
1\end{array}$ & $\begin{array}{l}12 \\
12 \\
12\end{array}$ & $\begin{array}{l}6 \\
5 \\
8\end{array}$ & $\begin{array}{l}1 \\
5\end{array}$ & & \\
\hline $\begin{array}{l}\text { Proteus } \\
\text { species }^{2}\end{array}$ & $\begin{array}{l}\text { Ampicillin } \\
\text { Chloramphenicol } \\
\text { Tetracycline }\end{array}$ & $\begin{array}{l}13 \\
13 \\
13\end{array}$ & 1.9 & $\begin{array}{l}5 \\
3\end{array}$ & $\begin{array}{l}2 \\
2\end{array}$ & $\begin{array}{l}2 \\
2 \\
1\end{array}$ & $\begin{array}{l}2 \\
1 \\
1\end{array}$ & & $\begin{array}{l}1 \\
3 \\
4\end{array}$ & $\begin{array}{l}1 \\
6\end{array}$ & 1 & 1 & 1 & \\
\hline
\end{tabular}

${ }^{1}$ Mainly paracolon organisms but including achromobacter sp. and Proteus inconstans.

${ }^{2}$ Proteus morganii, 10 strains; Proteus vulgaris, three strains. 
TABLE II

COMPARISON OF AMPICILLIN WITH NINE ANTIBIOTICS AGAINST GRAM-NEGATIVE BACTERIA AND ENTEROCOCCI

\begin{tabular}{|c|c|c|c|c|c|c|c|c|c|c|c|c|c|}
\hline \multirow[t]{2}{*}{ Organism } & \multirow{2}{*}{$\begin{array}{l}\text { Number } \\
\text { of Strains }\end{array}$} & \multirow[t]{2}{*}{ Antibiotic } & \multicolumn{11}{|c|}{ Minimum Inhibitory Concentrations ( $\mu g . / \mathrm{ml}$.$) and No. of Strains$} \\
\hline & & & $>500$ & 500 & 250 & 125 & 50 & 25 & $12 \cdot 5$ & $5 \cdot 0$ & $2 \cdot 5$ & $1 \cdot 25$ & 0.5 \\
\hline E. coli & 20 & $\begin{array}{l}\text { Ampicillin } \\
\text { Chloramphenicol } \\
\text { Colistin sulphate } \\
\text { Colistin methane } \\
\text { sulphonate } \\
\text { Cycloserine } \\
\text { Kanamycin } \\
\text { Nitrofurantoin } \\
\text { Polymyxin } \\
\text { Streptomycin } \\
\text { Tetracycline }\end{array}$ & $\begin{array}{l}2 \\
1 \\
1\end{array}$ & 2 & 1 & $\begin{array}{l}1 \\
1 \\
4 \\
3 \\
\\
2\end{array}$ & $\begin{array}{r}12 \\
3\end{array}$ & $\begin{array}{l}4 \\
1 \\
2 \\
1\end{array}$ & 10 & $\begin{array}{r}9 \\
13 \\
3 \\
1 \\
\\
3 \\
2 \\
2 \\
1\end{array}$ & $\begin{array}{r}6 \\
15\end{array}$ & $\begin{array}{r}16 \\
7 \\
9 \\
2\end{array}$ & 1 \\
\hline Proteus mirabilis & 20 & $\begin{array}{l}\text { Ampicillin } \\
\text { Chloramphenicol } \\
\text { Colistin sulphate } \\
\text { Colistin methane } \\
\text { sulphonate } \\
\text { Cycloserine } \\
\text { Kanamycin } \\
\text { Nitrofurantoin } \\
\text { Polymyxin } \\
\text { Streptomycin } \\
\text { Tetracycline }\end{array}$ & $\begin{array}{r}1 \\
19 \\
18\end{array}$ & 1 & $\begin{array}{r}1 \\
18\end{array}$ & $\begin{array}{r}19 \\
8\end{array}$ & 12 & 1 & $\begin{array}{r}16 \\
\\
6 \\
6 \\
11\end{array}$ & $\begin{array}{r}14 \\
8\end{array}$ & 2 & 15 & 2 \\
\hline Streptococcus faecalis & 20 & $\begin{array}{l}\text { Ampicillin } \\
\text { Chloramphenicol } \\
\text { Colistin sulphate } \\
\text { Colistin methane } \\
\text { sulphonate } \\
\text { Cycloserine } \\
\text { Kanamycin } \\
\text { Nitrofurantoin } \\
\text { Polymyxin } \\
\text { Streptomycin } \\
\text { Tetracycline }\end{array}$ & $\begin{array}{l}20 \\
20\end{array}$ & 15 & $\begin{array}{r}2 \\
11\end{array}$ & $\begin{array}{r}5 \\
18 \\
1\end{array}$ & $\begin{array}{l}8 \\
1\end{array}$ & $\begin{array}{r}3 \\
\\
5 \\
19 \\
2\end{array}$ & 11 & 1 & 6 & 20 & \\
\hline Aerobacter aerogenes & 10 & $\begin{array}{l}\text { Ampicillin } \\
\text { Chloramphenicol } \\
\text { Colistin sulphate } \\
\text { Colistin methane } \\
\text { sulphonate } \\
\text { Cycloserine } \\
\text { Kanamycin } \\
\text { Nitrofurantoin } \\
\text { Polymyxin } \\
\text { Streptomycin } \\
\text { Tetracycline }\end{array}$ & $\begin{array}{l}2 \\
1\end{array}$ & 2 & 2 & $\begin{array}{l}6 \\
5\end{array}$ & $\begin{array}{l}2 \\
2\end{array}$ & $\begin{array}{l}2 \\
1 \\
2\end{array}$ & $\begin{array}{l}1 \\
2 \\
8 \\
1 \\
1 \\
1\end{array}$ & $\begin{array}{l}6 \\
3\end{array}$ & $\begin{array}{l}2 \\
4 \\
1 \\
1\end{array}$ & $\begin{array}{l}2 \\
2 \\
6 \\
\\
7 \\
3\end{array}$ & \\
\hline Pseudomonas pyocyanea & 20 & $\begin{array}{l}\text { Ampicillin } \\
\text { Chloramphenicol } \\
\text { Colistin sulphate } \\
\text { Colistin methane } \\
\text { sulphonate } \\
\text { Cycloserine } \\
\text { Kanamycin } \\
\text { Nitrofurantoin } \\
\text { Polymyxin } \\
\text { Streptomycin } \\
\text { Tetracycline }\end{array}$ & 19 & 1 & $\begin{array}{l}11 \\
10 \\
18\end{array}$ & $\begin{array}{r}8 \\
6 \\
2 \\
2 \\
15\end{array}$ & $\begin{array}{r}18 \\
4 \\
\\
2 \\
4\end{array}$ & 1 & $\begin{array}{l}1 \\
1\end{array}$ & $\begin{array}{r}1 \\
19 \\
\\
19\end{array}$ & $\begin{array}{l}1 \\
1\end{array}$ & 1 & \\
\hline Mixed proteus ${ }^{1}$ & 9 & $\begin{array}{l}\text { Ampicillin } \\
\text { Chloramphenicol } \\
\text { Colistin sulphate } \\
\text { Colistin methane } \\
\text { sulphonate } \\
\text { Cycloserine } \\
\text { Kanamycin } \\
\text { Nitrofurantoin } \\
\text { Polymyxin } \\
\text { Streptomycin } \\
\text { Tetracycline }\end{array}$ & $\begin{array}{l}1 \\
6 \\
5 \\
1 \\
7 \\
3\end{array}$ & $\begin{array}{l}1 \\
1\end{array}$ & 1 & $\begin{array}{l}8 \\
6\end{array}$ & 2 & $\begin{array}{l}2 \\
1 \\
1\end{array}$ & $\begin{array}{l}2 \\
4 \\
1 \\
1\end{array}$ & $\begin{array}{l}3 \\
2 \\
\\
2 \\
1 \\
3\end{array}$ & $\begin{array}{l}3 \\
1 \\
1\end{array}$ & $\begin{array}{l} \\
4 \\
2 \\
2\end{array}$ & \\
\hline
\end{tabular}

${ }^{2}$ Three of $P$. morganii, one of $P$. inconstans, four of $P$. vulgaris, and one of $P$. rettgeri. 
With the strains of Pseudomonas pyocyanea, ampicillin, and also chloramphenicol and tetracycline, showed a very low order of activity.

ACTIVITY OF AMPICILLIN AND NINE OTHER ANTIBIOTICS Groups of 20 strains of each of the main species were selected at random from the total number of isolates and tested for antibiotic sensitivity to ampicillin, chloramphenicol, colistin sulphate, colistin methane sulphonate, cycloserine, kanamycin, nitrofurantoin, polymyxin, streptomycin and tetracycline. The minimum inhibitory concentration values are shown in Table II. Against the group of $E$. coli, colistin sulphate, kanamycin, polymyxin, streptomycin and tetracycline were all more active than ampicillin. Colistin methane sulphonate, however, was less active and cycloserine and nitrofurantoin were relatively ineffective.

Against $P$. mirabilis, ampicillin was markedly more active than any of the other antibiotics tested. Proteus mirabilis was tested as a separate group because this was the species of proteus most frequently encountered clinically. Results for a mixed group of nine proteus cultures comprising $P$. morganii, $P$. inconstans, $P$. vulgaris, and $P$. rettgeri are also shown in Table II. The minimum inhibitory concentration values were generally very variable for most of the antibiotics tested. At a level of $5.0 \mu \mathrm{g} . / \mathrm{ml}$. only two strains were inhibited by tetracycline and three by chloramphenicol. Four strains were inhibited by ampicillin at this level. Kanamycin and streptomycin were the most effective of the antibiotics tested against this group of organisms.

Ampicillin was outstandingly active against Streptococcus faecalis in comparison with the other antibiotics. Ampicillin, however, showed little activity against 10 strains of Aerobacter aerogenes, and chloramphenicol, colistin sulphate, kanamycin, polymyxin, and streptomycin all showed greater activity although resistant strains were observed with most of these antibiotics. Against Pseudomonas pyocyanea only polymyxin and colistin sulphate were active at concentrations of $5 \mu \mathrm{g} . / \mathrm{ml}$. Colistin methane sulphonate showed a considerably lower order of activity against this organism and none of the other antibiotics demonstrated significant activity.

\section{DISCUSSION}

The results obtained in this report with a fairly large number of clinical isolates from three different hospitals give some indication of the general sensitivity of Gram-negative bacilli and enterococci to ampicillin. Some comparisons can also be drawn between the activity of ampicillin and that of other:antibiotics in current use.

Taking the group of 673 isolates tested as a whole $\stackrel{\vec{P}}{+}$ $448(67 \%)$ were inhibited by ampicillin at a con-등 centration of $5 \mu \mathrm{g} . / \mathrm{ml}$. The corresponding figures $\overline{\bar{c}}$ for chloramphenicol and tetracycline were $42 \%$ and $\vec{\oplus}$ $38 \%$, respectively. Among the coliforms, strains of $\varrho$ $E$. coli were fairly sensitive to ampicillin whereascs strains of aerobacter were mostly resistant. Similarly, $\vec{\circ}$ with Proteus species, strains of Proteus mirabiliswere mostly sensitive to ampicillin whereas strains $\vec{\omega}$ of other Proteus species, such as $P$. morganii, $P$. vulgaris and $P$. rettgeri were generally resistant.. Ampicillin was notably active against Strep. $\vec{\nabla}$ faecalis. Strains of $E$. coli, Proteus mirabilis, and ${ }^{+}$ Strep. faecalis appear as the organisms mostor sensitive to ampicillin and these account for $75 \%$ of the total number of isolates tested in this work. They are also reported by Brumfitt et al. (1962) and Garrod, Shooter, and Curwen (1954) to be the organisms most frequently encountered in urinarytract infections.

Resistance to ampicillin was encountered, particu larly among strains of Aerobacter and Proteus species other than $P$. mirabilis. Unlike the resistance of staphylococci to penicillin $G$, the resistance of Gram-negative bacilli to ampicillin can be due iñ certain cases to penicillinase production, and im other cases to intrinsic resistance, and some bacteriक $\overrightarrow{5}$ exhibit both of these characteristics. Penicillinase production, however, does not always result in high degree of resistance to ampicillin. This is because ampicillin is significantly more stable thar penicillin $\mathrm{G}$ to the penicillinase produced by certain bacteria, and in particular certain strains of $E$. col (Auhagen, Gloxhuber, Hecht, Knott, Otten, Rauen's busch, Risse, Schmid, Scholtan, and Walter, 1962? Ayliffe, 1963; Percival, Brumfitt, and de Louvois 1963; Smith and Hamilton-Miller, 1963; Sutherland 1964). On the other hand ampicillin is generally less stable than penicillin $G$ to the penicillinase produced by aerobacter strains (Smith and Hamilton-Miller 1963) and the resistance which these strains generallyo show to ampicillin is usually associated with inactivation of the drug (Ayliffe, 1963; Sutherland $d_{0}^{\omega}$ 1964). In contrast, the resistance of Pseudomonds pyocyanea to ampicillin is due entirely to intrinsie insensitivity, ampicillin being extremely stable to th\& penicillinase produced by these organisms (Sutherland, 1964).

The authors are indebted to Dr. A. Knudsen, of the Wesึ Middlesex Hospital, Isleworth, Dr. M. Ridley, of Sf Thomas's Hospital, London, and Dr. R. E. M. Thompsonf, Bland Sutton Institute of Pathology, Middlesex Hospit及ु 
Medical School, London, for the cultures used in this work.

\section{REFERENCES}

Acred, P., Brown, D. M., Turner, D. H., and Wilson, M. J. (1962). Brit. J. Pharmacol., 18, 356.

Auhagen, E., Gloxhuber, Ch., Hecht, G., Knott, Th., Otten, H., Rauenbusch, E., Risse, K. H., Schmid, J., Scholtan, W., and Walter, A. M. (1962). Arzneimittel-Forsch., 12, 791

Ayliffe, G. A. J. (1963). J. gen. Microbiol., 30, 339.

Brumfitt, W., Percival, A., and Carter, M. J. (1962). Lancet, 1, 130.

Bunn, P. A. (1961). Antimicrobial Agents and Chemotherapy, 739.

Garrod, L. P., Shooter, R. A., and Curwen, M. P. (1954). Brit. med. J. 2, 1003.

Knudsen, E. T., Rolinson, G. N., and Stevens, S. (1961). Ibid., 2, 198.

Lowe, G. H. (1962). J. med. Lab. Technol., 19, 21.
Mackie, T. J., and McCartney, J. E. (1962). Handbook of Bacteriology, 10th ed., edited by $R$. Cruickshank, p. 619. Livingstone, Edinburgh and London.

Percival, A., Brumfitt, W., and de Louvois, J. (1963). J. gen. Microbiol., 32, 77.

Rolinson, G. N., and Stevens, S. (1961). Brit. med. J., 2, 191.

Rutenberg, A. M., Greenberg, H. L., Schweinburg, F. B., and Perreault, M. A. (1961). Antimicrobial Agents and Chemotherapy, 749.

Smith, J. T., and Hamilton-Miller, J. M. T. (1963). Nature (Lond.), $197,976$.

Stewart, D. J. (1961). Ibid., 191, 521.

Stewart, G. T., Coles, H. M. T., Nixon, H. H., and Holt, R. J. (1961). Brit. med. J., 2, 200.

Sutherland, R. (1964). J. gen. Microbiol., 34, 85.

Thornley, M. J. (1960). J. appl. Bact., 23, 37.

Trafford, J. A. P., Maclaren, D. M., Lillicrap, D. A., Barnes, R. D. S., Houston, J. C., and Knox, R. (1962). Lancet, 1, 987. 